Folia Historica Cracoviensia, 22: 2016, s. 437-450

DOI: http://dx.doi.org/10.15633/fhc.2089

Agnieszka Skrodzka

Uniwersytet KardynaŁa Stefana Wyszyńskiego

\title{
Królewicz jezuitą, król opatem. Wątek „zakonny” w ikonografii Jana Kazimierza
}

Królewicz Kazimierz Waza, przyszły król Polski Jan II Kazimierz, syn Zygmunta III i Konstancji Habsburżanki, wzrastał w atmosferze pogłębionej pobożności, jaka panowała na dworze jego rodziców. Ton ten nadawała w pierwszym rzędzie monarsza para, bardzo religijna, otaczająca się uczonymi jezuitami i pilnująca, by królewscy synowie byli wychowywani w duchu bojaźni bożej. Z pewnością przyczyniło się to do rozwinięcia się życia duchowego młodego królewicza, który chciał nawet poświęcić się Bogu. Losy ostatecznie przeznaczyły mu najwyższe świeckie stanowisko. Do realizacji pragnień duchowych Jan Kazimierz powrócił po swej abdykacji. Jednak o ile jego koronacja oraz panowanie tego króla są dobrze i bogato udokumentowane przez ikonografię, jego epizody „zakonne” odzwierciedlone w sztuce epoki pozostają praktycznie nieznane. Niniejszy artykuł prezentuje, w dużym skrócie, niewielką grupę tych ciekawych obiektów.

W wieku 32 lat królewicz postanowił wstąpić do zakonu jezuitów. W marcu 1641 roku informacja ta została przekazana w wielkiej tajemnicy włoskiemu wizytatorowi jezuitów Fabriziemu Banfiemu․ . Dopiero pół roku później dowiedział się o tym Władysław Iv, który ostro wyraził swój sprzeciw. Starszy Waza interweniował nawet u samego papieża Urbana VIII. Protesty jednak tymczasowo nic nie dały. W maju 1643 roku królewicz w sekrecie wyjechał do jezuitów w Loreto. We wrześniu tego roku przyoblekł suknię zakonną ${ }^{2}$. Nowicjusz początkowo mocno obstawał przy swym zamiarze poświęcenia się Bogu, gorliwie podejmując wszelkie wymogi życia klasztornego. Dążył także usilnie do uzyskania dyspensy na święcenia kapłańskie przed terminem kanonicznym ${ }^{3}$. Po ponad roku trwania w nowicjacie zmienił zdanie. Doszło do tego między innymi wskutek stałego

\footnotetext{
Zob. T. Wasilewski, Ostatni Waza na polskim tronie, Katowice 1984, s. 39.

Zob. T. Wasilewski, Ostatni Waza..., dz. cyt., s. 40, 44.

Zob. T. Wasilewski, Ostatni Waza..., dz. cyt., s. 42-44.
} 
i intensywnego nacisku wywieranego na Ojca Świętego, biskupów i przełożonych jezuickich przez króla Władysława. Pojawił się wówczas pomysł nadania Kazimierzowi kapelusza kardynalskiego, z czym wiązałaby się możliwość opuszczenia jezuitów w sposób honorowy. 28 maja 1646 roku Innocenty x nadał Kazimierzowi godność kardynała, która jednocześnie uwalniała go z zakonu na mocy specjalnego polecenia papieskiego ${ }^{4}$.

Tę nominację upamiętnił emblemat Rubet cum deserit / orbem, nieznany do tej pory obiegowi naukowemu. Sama łacińska lemma, bez ikonu, została opublikowana w związku z Kazimierzem po raz pierwszy przez jezuitę Claude'a-François Ménestriera w jego dziele Philosophia imaginum (1695) ${ }^{5}$. Emblemat $\mathrm{z}$ tą samą lemmą znajdziemy w słynnym dziele Jakoba Boscha, również członka Societatis Iesu. Mowa o Symbolographia, sive, De arte symbolica, druku wydanym po raz pierwszy w roku 1702. W części ilustracyjnej widzimy kartusz z przedstawieniem słońca o ludzkiej twarzy znajdującego się w linii horyzontu utworzonej przez pagórkowaty krajobraz (il. 1). Lemma w kartuszu wyżej objaśnia, że został tu przedstawiony wieczorny zachód rzucający czerwone blaski na zgromadzone na niebie chmury. Zachodzącym słońcem jest królewicz Kazimierz, który opuszcza świat, ponieważ został zaliczony w poczet kardynałów Świętego Kościoła Rzymskiego. Wspomniana purpura to, rzecz jasna, kolor kardynalskiej mozzetty. Te dwa przykłady potwierdzają, jak bardzo usatysfakcjonowani byli jezuici z powodu wstąpienia do ich zakonu tak dostojnego księcia, krewnego najpotężniejszych władców europejskich i brata samego króla Polski.

Wiadomo mi także o dwóch olejnych portretach królewicza Kazimierza jako kardynała. Pierwszy z nich znajduje się w refektarzu kolegium jezuitów w Loyoli w Hiszpanii ${ }^{6}$. Niestety nie ma o nim bliższych informacji. Nieokreślony jest jego autor ani data powstania. Nie ustalono, jakimi drogami trafił na Półwysep Iberyjski. Wydaje się, że mamy do czynienia z dobrą kopią z epoki, a może nawet autorskim powtórzeniem portretu en pied $\mathrm{w}$ mniejszej skali, tj. w ujęciu w 3/4. Omawiane płótno to obraz dobrego pędzla, wiarygodnie odtwarzający rysy młodszego Wazy: kształt twarzy, jego wysuniętą, „habsburską” dolną szczękę oraz oczy o dużych powiekach nadające obliczu nieco melancholijny wygląd. Czy można w autorze dopatrywać się Daniela Schultza? Trudno powiedzieć. Nie

\footnotetext{
4 Zob. T. Wasilewski, Ostatni Waza..., dz. cyt., s. 45, 46, 47-51.

5 Zob. C. F. Ménestrier, Philosophia Imaginum id est Sylloge Symbolorum Amplissima [...], Amstelodami-Gedani MDCLXXXv, s. 117, nr LXVI.

${ }^{6}$ Reprodukcja obrazu przy haśle Jan Kazimierz, s.v., [w:] Encyklopedia wiedzy o jezuitach na ziemiach Polski i Litwy 1564-1995, oprac. L. Grzebień, Kraków 2004, s. 236-237.
} 
wiadomo nic na temat ewentualnego pobytu tego artysty w Wiecznym Mieście w interesującym nas okresie ${ }^{7}$. Kazimierz wyjechał we wrześniu 1646 roku z Włoch nie w purpurze kardynalskiej, tylko w stroju świeckim, ale swojej godności zrzekł się dopiero w listopadzie. Do Polski wjechał już po swej rezygnacji ${ }^{8}$. Drugi portret kardynała Kazimierza Wazy (il. 2) znajdował się przed II wojną światową w rzymskim kościele Il Gesù?. Jest to zapewne zmniejszona kopia wcześniejszego wizerunku, także wykazująca cechy wykonania przez malarza o dobrym warsztacie.

Znana jest mi również jedna rycina późniejsza, pochodząca już z wieku XVIII, a związana $\mathrm{z}$ wątkiem zakonnym królewicza Wazy ${ }^{10}$. Ukazuje ona portrety dwóch polskich władców: Jana Kazimierza oraz Stanisława Leszczyńskiego - obydwaj, jak wiadomo, abdykowali i zamieszkali po tym fakcie we Francji. Jan Kazimierz prezentuje na niej leżący na stole jezuicki strój duchowny, czyli czarną suknię zakonną z rzędem małych guzików oraz biret. W tle rysuje się fragment sylwetki najprawdopodobniej wyimaginowanego kościoła. Umieszczony poniżej komentarz podkreśla, że losami ludzkimi rządzi szczęście, czyli fortuna, która jest w stanie odnaleźć swego wybrańca nawet w klasztorze. Jednocześnie wskazuje, że najwyższe stanowiska i zaszczyty nie zawsze przynoszą oczekiwaną słodycz. Może je natomiast zapewnić życie w klauzurze (il. 3).

Rezygnacja królewicza Kazimierza z godności kardynalskiej doczekała się swego usprawiedliwienia w sztuce, ale dopiero dwa lata później, w jego medalu koronacyjnym z 1648 roku $^{11}$ (il. 4). Widnieje na nim uzbrojona Manus Dei trzymająca kłódkę szyfrową z napisem Ioanes / Casimi / rvs. Lemma na tym medalu głosi: Compactvm est desuper. Jak wykazał Jakub Pokora, koncept medalu został oparty o słowo clavstrum, homonim, który oznacza zarówno „kłódkę”, jak i „klasztor”. Program ideowy numizmatu przywołuje zatem oczywisty dla współczesnych epizod sprzed kilku miesięcy, czyli wystąpienie królewicza z za-

7 Nic o tym w: B. Steinborn, Malarz Daniel Schultz, gdańszczanin w służbie królów polskich, Warszawa 2004.

8 Zob. T. Wasilewski, Ostatni Waza..., dz. cyt., s. 51-52.

9 Zob. G. Gerola, Le fonti italiane per la iconografia dei reali di Polonia, Firenze 1939, s. 37, 74.

10 Tego typu rycina znajduje się np. w zbiorach Muzeum Książąt Czartoryskich w Krakowie, sygn. R.2440.

${ }_{11}$ Zob. J. Pokora, Wazowskie zagadki: wieńce Zygmunta i obeliski Władysława oraz kłódka Jana Kazimierza, [w:] J. Pokora, Psy, błazny, dzieci, królowie... Studia nad sztuka XV-XVIII wieku, Warszawa 2006, s. 181-183; T. Panfil, Numizmaty w polskim ceremoniale dworskim XVI-XVII wieku, [w:] Studia nad sztuka renesansu i baroku, t. 9: Ceremoniat i obyczaj w XVI-XVIII wieku, red. J. Lileyko, I. Rolska-Boruch, Lublin 2008, s. 152, 154. 
konu. Wnioskujemy z niego, że to sama Opatrzność wyprowadziła Kazimierza z klasztoru po to, by mógł zostać królem Rzeczpospolitej.

$Z$ epizodem nowicjatu związane jest wydarzenie podawane przez Wespazjana Kochowskiego w jego Klimakteriach (1683). Młody królewicz Kazimierz, pragnąc zostać jezuitą, dwukrotnie podobno spotkał się ze świątobliwym mnichem franciszkańskim Giuseppem da Copertino i wypytywał go o swoją przyszłość. Zakonnik miał wówczas powiedzieć: „Ach! Będziesz królem, ale i tobie niepomyślnym, i poddanym nieszczęśliwym uprzykrzysz się królowaniem" ${ }^{12}$. Moment wygłoszenia przepowiedni stał się tematem XVIII-wiecznego fresku z kościoła św. św. Janów w Brnie ${ }^{13}$ (il. 5). Królewicz Kazimierz, w stroju polskim, nieśmiało wskazuje na trzymany przez stojącego za nim jezuitę biret kardynalski. Stanowczy gest pobożnego zakonnika, prezentującego jawiące się za murami świątyni krzesło królewskie, rozjaśnia wyroki Opatrzności.

Panowanie króla Jana Kazimierza (1648-1668) wypełniały liczne przeciwności. Lata „potopu” były szczególnie dla niego trudne - monarcha cierpiał na depresję i już wtedy zaczął myśleć o rezygnacji. Poważniejsze kroki ku temu rozwiązaniu podjął w 1666 roku, kiedy to podpisał z Ludwikiem xIV układ, na mocy którego zobowiązał się do abdykacji. Król Francji obiecał mu za to między innymi dochody z dóbr duchownych. Jan Kazimierz planował, że po rezygnacji z panowania powróci do pogłębionego życia religijnego w którymś z klasztorów w Europie ${ }^{14}$.

Jednym $\mathrm{z}$ wówczas powstałych dzieł sztuki, $\mathrm{w}$ którym pojawia się wątek „,zakonny", jest rycina alegoryczna stanowiąca ilustrację utworu napisanego na abdykację Jana Kazimierza, wydanego po 1668 roku w Gdańsku ${ }^{15}$. Sztych ukazuje pokaźnych

${ }_{12}$ W. H. Kochowski, Historia panowania Jana Kazimierza z klimakteriów Wespazjana Kochowskiego [...], t. 3, Poznań 1859, s. 184-185; G. Parisciani, San Giuseppe da Copertino e la Polonia, Padova 1988, s. 61.

13 Zob. G. Parisciani, San Giuseppe..., dz. cyt., s. 39-69.

14 Zob. Z. Wójcik, Jan Kazimierz Waza, Wrocław 1997, s. 109, 112; K. Waliszewski, Polsko-francuskie stosunki $w$ XVII wieku, 1644-1667. Opowiadania i źródła historyczne ze zbiorów archiwalnych francuskich publicznych i prywatnych [...], Kraków 1889, s. 258-259.

15 Zob. A. Kurkowa, Grafika ilustracyjna gdańskich druków okolicznościowych XVII wieku, Wrocław 1979, s. 184-188; A. Kurkowa, Gdański utwór okolicznościowy z 1668 r., poświęcony abdykacji Jana Kazimierza, „Rocznik Gdański” 41 (1981) z. 1, s. 149-158; J. A. Chrościcki, O symbolice władzy, [w:] Literatura i kultura polska po „Potopie”, red. B. Otwinowska, J. Pelc, B. Falęcka, Wrocław 1992, s. 48-49; E. Kotarski, Gdańska poezja okolicznościowa XVII wieku, Gdańsk 1993, s. 81, 93-94; S. K. Kuczyński, Polskie herby ziemskie. Geneza, treści, funkcje, Warszawa 1993, s. 155-156; M. Heydel, Bensheimer Johann, [w:] Allgemeines Künstler-Lexikon. Die Bildenden Künstler aller Zeiten Und Völker, Bd. 9, Hrsg. K. G. Saur, München-Leipzig 1994, s. 148; K. J. [K. Jackowska], Ilustracja do druku na abdykację Jana Kazimierza, [w:] Orzet i Trzy Korony. Sąsiedztwo polsko- 
rozmiarów otwarty namiot, zwieńczony baldachimem. We wnętrzu znajdują się trzy przedstawienia w owalnych wieńcach, zawierające symbolicznie zobrazowane etapy życia Jana Kazimierza. Pierwsze od lewej jest obramowane kwiatami róż i lilii. Jego środek zajmuje stół $\mathrm{z}$ insygniami władzy monarszej. W tle widoczne są baszty posadowione na wysokich skałach. Prezentowany stół to symbol Rzeczpospolitej, która ofiarowuje regalia nowemu elektowi. W murach twierdzy można domyślać się chyba murów Sisteron, francuskiego więzienia królewicza Kazimierza, do którego trafił przed okresem nowicjatu. Tę interpretację mogą potwierdzać lilie, symbol czystości i niewinności, zapewne aluzja do lat młodzieńczych królewicza, a szczególnie może do jego okresu jezuickiego. Drugi wieniec składa się z liści dębu, żołędzi oraz gałęzi palmowych. Głównym elementem jest tu monumentalny Snopek z regaliami na kłosach. Zza godła wyłania się pole bitewne, $\mathrm{z}$ walczącym wśród kłębów dymu wojskiem. Scena ta ilustruje burzliwe panowanie Jana Kazimierza. Trzeci wieniec jest złożony z liści wawrzynu i kwiatów trzciny ${ }^{16}$. W jej wnętrzu wyobrażono ołtarz z insygniami królewskimi. W tle rozciąga się panorama miasta z klasztorem i zamkiem na wysokiej skarpie. Kwietną ramę wieńczy korona $\mathrm{w}$ otoku $\mathrm{z}$ cierniowych gałązek. To ostatni okres życia Jana Kazimierza i symbolicznie ukazany akt abdykacji. Korona w otoku $\mathrm{z}$ wieńca cierniowego, a także wiechy trzciny przywołują na myśl narzędzia męki Chrystusa. Widoczne tu zabudowania to, jak się wydaje, zamek warszawski oraz niezidentyfikowany klasztor. Abdykujący Jan Kazimierz został tu zatem porównany do Mesjasza, który stał się z władcy sługą i zamienił koronę oraz berło na ciernie i trzcinę. W kwietniu 1669 roku Jan Kazimierz wyjechał z kraju. Został powitany przez Ludwika XIV w jego zamku w Saint-Germain-en-Laye. Niewiele dziś wiadomo o spotkaniu władców, znane jest natomiast jego zobrazowanie w sztuce ${ }^{17}$. Również ta scena nie jest ściśle faktograficzna, zawiera w sobie spory ładunek alegorii. W centrum Ludwik xIv ujmuje prawą dłonią w przyjacielskim geście rękę Jana Kazimierza. Obaj władcy odziani są w stroje dworskie i nie posiadają

-szwedzkie nad Bałtykiem w epoce nowożytnej (XVI-XVIII w.), katalog wystawy, red. D. Galas, Warszawa 2002, s. 177-178, nr II 72; B. Pfeiffer, „Coelum et regnum”. Studia nad symbolika państwa $i$ władcy w polskiej literaturze i sztuce XVI $i$ XVII stulecia, Zielona Góra 2002, s. 52, przyp. 55; s. 125; J. Talbierska, Rytownicy gdańscy dla królów i dostojników polskich, [w:] Gdańsk dla Rzeczpospolitej w stużbie Króla i Kościoła, red. J. Talbierska, Warszawa 2004, s. 89; A. Skrodzka, Wizerunek króla nieszczęśliwego - portret Stanisława Augusta z klepsydrą, „Biuletyn Historii Sztuki” (2007) nr 3-4, s. 232.

${ }^{16}$ U Kurkowej: papirus; A. Kurkowa, Gdański..., dz. cyt., s. 154.

${ }_{17}$ M. Hennin, Inventaire de la collection d'estampes relatives à l'histoire de France léguée en 1863 à la Bibliothèque Nationale, t. II, 1 partie, Paris 1878, s. 95. 
atrybutów wyróżniających ich rangę. Obaj też mają odkryte głowy, co zgodnie $\mathrm{z}$ ceremoniałem podkreśla równość ich pozycji. Tuż za Królem Słońce widzimy także personifikację Francji, wyciągającą w stronę gościa dary: albę i mitrę opacką, stanowiące rekompensatę za porzucenie tronu.

Już w czasie pobytu Jana Kazimierza w Paryżu powstało dzieło zatytułowane Joanni Casimiro, Regi Poloniae et Sueciae. Post abdicata regna Lutetiam venienti $i^{18}$. Jego autorem był Charles de la Rue (1643-1725), jeden z najwybitniejszych oratorów Towarzystwa Jezusowego w XviI wieku. Utwór wydano w Paryżu w 1670 roku. Wznawiano go kilkakrotnie. W wydaniu z 1672 roku, opublikowanym jeszcze przed śmiercią króla-opata, do utworu w języku łacińskim dołączono emblemat (il. 6). Prezentuje on leżący na stole owoc granatu, częściowo obrany z łupiny i ukazujący liczne nasiona. Pozostałości skórki, wraz z koroną jabłka, spoczywają obok na blacie. Do nich to właśnie odnoszą się słowa lemmy: POSITUM EST QVOD VILIUS. Owoc granatu z pozostałością kwiatu na jego wierzchołku w ikonografii symbolizował osobę monarchy ${ }^{19}$. Emblemat na Jana Kazimierza, $\mathrm{z}$ tą samą lemmą, pojawił się również w Symbolographii Boschiusa: Et, ex Rege deinde Abbas ad S. Germani in Gallia. Malum Granatum cortice suo spoliatum. L. [emma] positum est qvod vilius. P. La Rue ${ }^{20}$.

Jeszcze jedno dzieło, związane $\mathrm{z}$ wątkiem opackim Jana Kazimierza, to nagrobek jego serca w paryskim kościele Saint-Germain-des-Prés (il. 7). Król-opat zmarł 16 grudnia 1672 roku w Nevers. Serce monarchy wyjęto i pochowano w kościele Saint-Germain ${ }^{21}$. Przygotowaniem pomnika zajęli się Gaspard i Balthazar Marsy. Dzisiejszy wygląd nagrobka różni się od wyglądu oryginalnego, co związane było ze zniszczeniami w czasie rewolucji. Obecnie na cokole leży płyta, na której klęczy postać Jana Kazimierza, zwrócona pierwotnie w stronę ołtarza $\mathrm{z}$ wizerunkiem św. Kazimierza, patrona króla, dziś zaś z posągiem św. Franciszka Ksawerego. Monarcha ubrany jest $\mathrm{w}$ albę i nałożoną na nią dalmatykę, na plecach ma narzuconą kapę koronacyjną, która zdaje się lekko zsuwać. Król prawicą zdejmuje ją z barku. Lewe, ugięte $w$ łokciu ramię wyciąga $z$ uniżeniem i czcią ku ołtarzowi. W dłoni monarcha dzierży regalia - koronę i berło. Poniżej, w cokole od frontu,

18 Zob. C. de la Rue, Joanni Casimiro regi Poloniae et Sueciae. Post abdicata regna Lutetiam venienti, [w:] C. de la Rue, Idyllia, tertia editio auctior, Parisiis mdclxxiI, s. 46-49.

19 Zob. J. F. Leopold, Emblematisches Lust-Cabinet: mit 52. Neu inventirten Curiosen und durch Lateinisch-Französisch Italianisch- und Teutsche Beyschrifften erklärten Sin[n]-Bildern, [Augsburg] 1700, nr 20.

${ }^{20}$ Zob. J. Boschius, Symbolographia, sive, De arte symbolica: sermones septem, Augsburg MDCCII, s. 47, nr DCXLIII.

${ }^{21}$ Ciało pochowano tymczasowo w Nevers, a w 1676 roku w Krakowie. 
znajduje się płaskorzeźbiona scena zwycięstwa pod Beresteczkiem, w centrum z postacią króla galopującego na koniu ${ }^{22}$. Początkowo w kluczu obramienia niszy nagrobka znajdowała się grupa aniołków, które unosiły ku górze serce, mitrę opacką oraz pastorał.

Wątki ideowe pojawiające się w tym pomniku są bardzo liczne ${ }^{23}$. Jeden z nich związany jest ściśle, jak przypuszczam, z kwestią „zakonną”. Inskrypcja nagrobna sławi ziemskie - militarne zwycięstwa króla, z których najdonioślejsze zostało ukazane na tablicy. Autor napisu porównuje ich wspaniałość do największej duchowej cnoty króla - pobożności. Jej z kolei świadectwem jest górna część pomnika, ze sceną abdykacji. Rezygnacja $z$ korony jawi się tu jako czyn wynikający z religijności króla. Monarcha jest ukazany jako pogrążony w modlitwie (vita contemplativa), w przeciwieństwie do reliefu, gdzie jako dowódca prowadzi wojsko do walki (vita activa). Być może projektodawca nagrobka chciał zobrazować $\mathrm{w}$ ten sposób benedyktyńską dewizę ora et labora, stanowiącą przecież fundament życia religijnego wspólnoty Saint-Germain. Jeśli przypuszczenia te są słuszne, Jan Kazimierz na paryskim nagrobku jawiłby się zatem jako król doskonały: wojownik i opat, przy czym tę ostatnią funkcję przywoływałyby także, nieistniejące dziś, mitra i pastorał.

Powyższy przegląd udowadnia, że krótki klasztorny epizod i błyskawiczna kariera w hierarchii rzymskokatolickiego duchowieństwa polskiego królewicza Kazimierza były dobrze znane opinii publicznej, także dzięki przekazom ikonograficznym. Zarówno te, jak i późniejsze przedstawienia, związane z nominacją króla Jana Kazimierza na opata, miały utwierdzić jego pozytywny odbiór przez współczesnych. Wyłania się z nich obraz monarchy bardzo pobożnego, który porzucił swój tron z powodu racji wyższych. Nie był to wizerunek do końca zgodny z prawdą, ale za to spełniający ambicje osób, w których interesie leżało utrzymywanie kontaktów z byłym królem Polski.

${ }^{22}$ Zob. W. Tomkiewicz, Grobowiec Jana Kazimierza w kościele Saint-Germain-des-Prés w Paryżu, „Biuletyn Historii Sztuki” 5 (1937) 2, s. 132.

${ }^{23}$ Zostaną one omówione w innym miejscu. 


\section{Bibliografia}

\section{Źródła}

Boschius J., Symbolographia, sive, De arte symbolica: sermones septem, Augsburg MDCCII, s. 47, nr DCXLIII.

Gespräche In Dem Reiche derer Todten, Neun und dreyßigste Entrevuë, Zwischen Zweyen Königen von Polen, nemlich Sigismundo III. und seinem Sohn Joh. Casimiro II. [...], Leipzig 1721.

Kochowski W. H., Historia panowania Jana Kazimierza z klimakteriów Wespazjana Kochowskiego [...], t. 3, Poznań 1859.

Leopold J. F., Emblematisches Lust-Cabinet: mit 52. Neu inventirten Curiosen und durch Lateinisch-Französisch Italianisch- und Teutsche Beyschrifften erklärten Sin[n]-Bildern, [Augsburg] 1700, nr 20.

Ménestrier C. F., Philosophia Imaginum id est Sylloge Symbolorum Amplissima [...], Amstelodami-Gedani MDCLXXXv, s. 117, nr LXVI.

Rue de la C., Joanni Casimiro regi Poloniae et Sueciae. Post abdicata regna Lutetiam venienti, [w:] C. de la Rue, Idyllia, tertia editio auctior, Parisiis MDCLXXII.

\section{Opracowania}

Chrościcki J. A., O symbolice władzy, [w:] Literatura i kultura polska po „Potopie”, red. B. Otwinowska, J. Pelc, B. Falęcka, Wrocław 1992, s. 47-52.

Gerola G., Le fonti italiane per la iconografia dei reali di Polonia, Firenze 1939.

Heydel M., Bensheimer Johann, [w:] Allgemeines Künstler-Lexikon. Die Bildenden Künstler aller Zeiten Und Völker, Bd. 9, Hrsg. K. G. Saur, München-Leipzig 1994, s. 148.

Jan Kazimierz, s.v., [w:] Encyklopedia wiedzy o jezuitach na ziemiach Polski i Litwy 1564-1995, oprac. L. Grzebień, Kraków 2004, s. 236-237.

K. J. [Jackowska K.], Ilustracja do druku na abdykację Jana Kazimierza, [w:] Orzeł i Trzy Korony. Sąsiedztwo polsko-szwedzkie nad Battykiem w epoce nowożytnej (XVI-XVIII w.), katalog wystawy, red. D. Galas, Warszawa 2002, s. 177-178, nr II 72.

Kotarski E., Gdańska poezja okolicznościowa XVII wieku, Gdańsk 1993.

Kuczyński K., Polskie herby ziemskie. Geneza, treści, funkcje, Warszawa 1993.

Kurkowa A., Gdański utwór okolicznościowy z 1668 r., poświęcony abdykacji Jana Kazimierza, „Rocznik Gdański” 41 (1981) z. 1, s. 149-158.

Kurkowa A., Grafika ilustracyjna gdańskich druków okolicznościowych XVII wieku, Wrocław 1979.

Panfil T., Numizmaty w polskim ceremoniale dworskim XVI-XVII wieku, [w:] Studia nad sztuką renesansu i baroku, t. 9: Ceremoniał i obyczaj $w$ XVI-XVIII wieku, red. J. Lileyko, I. Rolska-Boruch, Lublin 2008, s. 149-164. 
Parisciani G., San Giuseppe da Copertino e la Polonia, Padova 1988.

Pfeiffer B., „Coelum et regnum”. Studia nad symbolika państwa $i$ władcy $w$ polskiej literaturze i sztuce XVI i XVII stulecia, Zielona Góra 2002.

Pokora J., Wazowskie zagadki: wieńce Zygmunta i obeliski Władysława oraz kłódka Jana Kazimierza, [w:] J. Pokora, Psy, błazny, dzieci, królowie... Studia nad sztuka XV-XVIII wieku, Warszawa 2006, s. 165-195.

Skrodzka A., Wizerunek króla nieszczęśliwego - portret Stanisława Augusta z klepsydra, „Biuletyn Historii Sztuki” (2007) nr 3-4, s. 203-247.

Steinborn B., Malarz Daniel Schultz, gdańszczanin w służbie królów polskich, Warszawa 2004 .

Talbierska J., Rytownicy gdańscy dla królów i dostojników polskich, [w:] Gdańsk dla Rzeczpospolitej w służbie Króla i Kościoła, red. J. Talbierska, Warszawa 2004, s. 89-101.

Tomkiewicz W., Grobowiec Jana Kazimierza w kościele Saint-Germain-des-Prés w Paryżu, „Biuletyn Historii Sztuki” 5 (1937) 2, s. 115-140.

Waliszewski K., Polsko-francuskie stosunki w XVII wieku, 1644-1667. Opowiadania i źródła historyczne ze zbiorów archiwalnych francuskich publicznych i prywatnych [...], Kraków 1889.

Wasilewski T., Ostatni Waza na polskim tronie, Katowice 1984.

Wójcik Z., Jan Kazimierz Waza, Wrocław 1997.

\section{Abstrakt}

Królewicz Kazimierz Waza wychowywał się na dworze swego ojca Zygmunta III w atmosferze pogłębionej pobożności. Skutkiem tego było jego wstąpienie do zakonu jezuitów. Królewicz ostatecznie opuścił klasztor i sięgnął po koronę królewską. Do życia zakonnego powrócił po swej abdykacji. Niniejszy artykuł prezentuje dzieła sztuki upamiętniające związki Jana Kazimierza z życiem zakonnym. Wśród nielicznej grupy są: emblemat, medal i ryciny, a także nagrobek Jana Kazimierza w Paryżu. Wszystkie te obiekty są świadectwem głębokiej pobożności Jana Kazimierza.

\section{Słowa kluczowe}

Zygmunt III Waza, ikonografia, jezuici, abdykacja, pobożność 


\begin{abstract}
The prince as a Jesuit, the king as an abbot. The "monastic" theme in the iconography of John II Casimir

The young Casimir Vasa was brought up at the court of his father, Sigismund III Vasa, in the atmosphere of great devotion, which made him enter the order of Jesuits. Even though he decided to leave the monastery and to take the Polish crown, he came back to the life of a monk after his abdication. The present paper presents the very few pieces of art commemorating the monastic life of John Casimir: an emblem, a medal, some prints and his tomb in Paris. All those objects demonstrate the deep piety of the king.
\end{abstract}

\title{
Keywords
}

Sigismund III Vasa, iconography, Jesuits, abdication, piety 

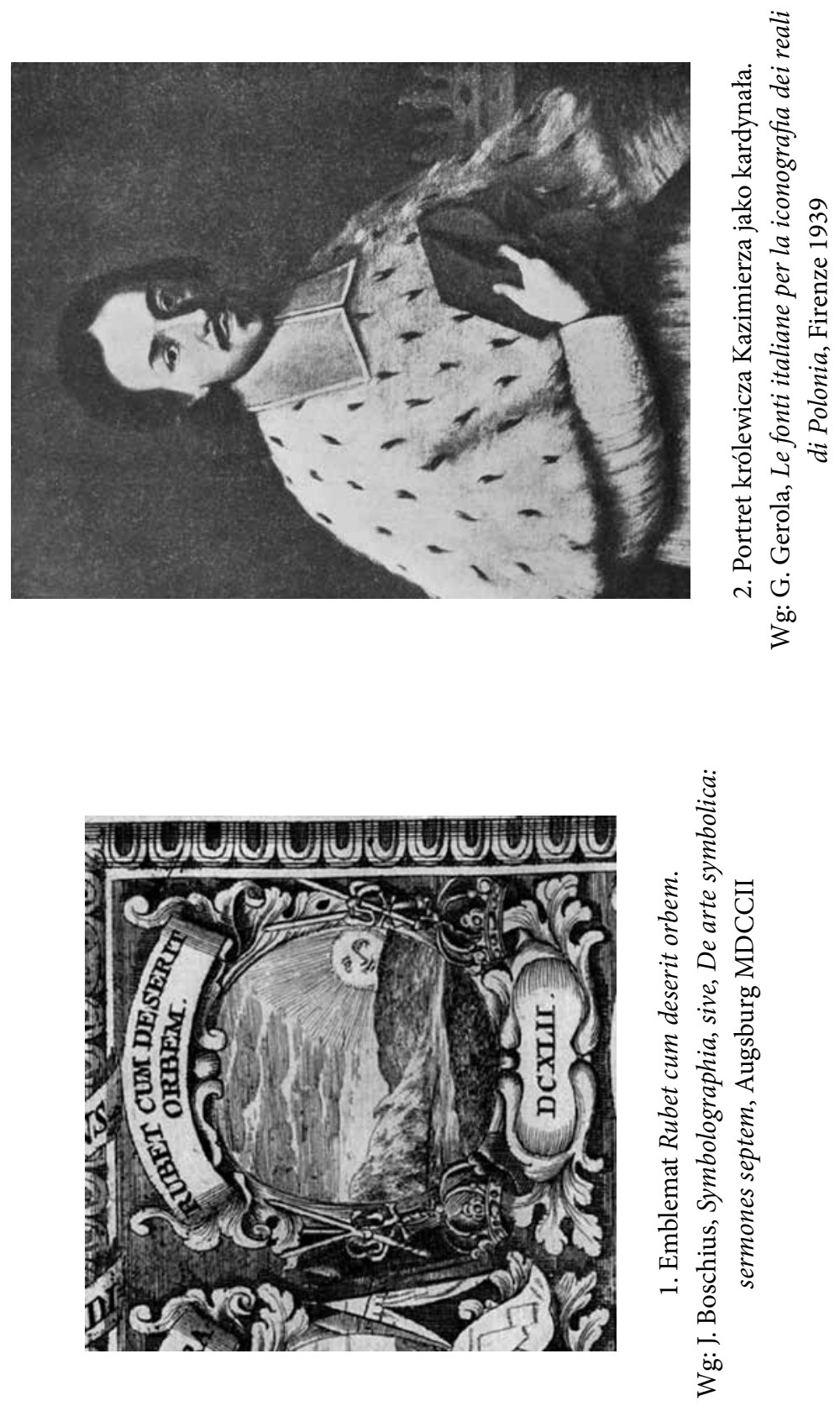


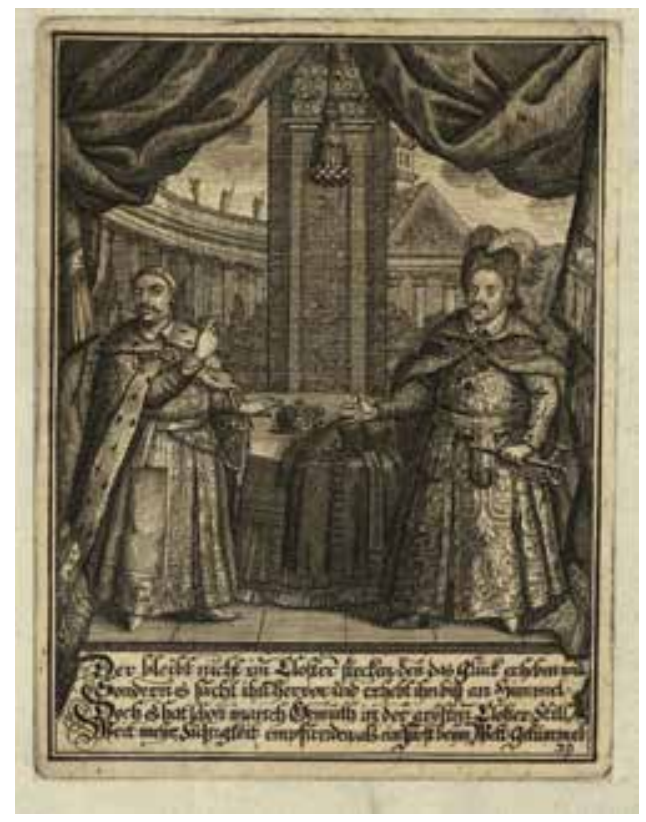

3. Jan Kazimierz jako eksjezuita, 1721 - wg: Gespräche In Dem Reiche derer Todten, Neun und dreyßigste Entrevuë, Zwischen Zweyen Königen von Polen, nemlich Sigismundo III. und seinem Sohn Joh. Casimiro II. [...], Leipzig 1721

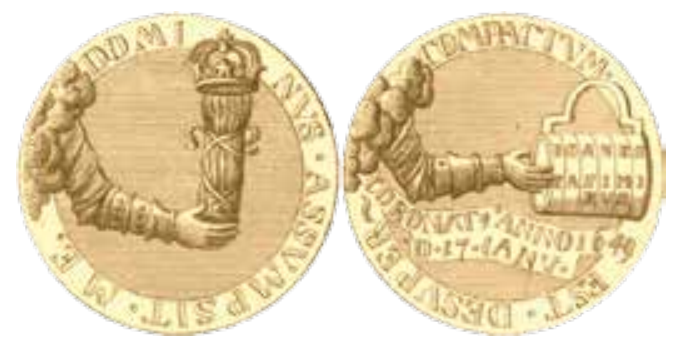

4. Medal koronacyjny Jana Kazimierza. Wg: E. Raczyński, Gabinet medalów polskich oraz tych które się dziejów Polski tyczą począwszy od najdawniejszych aż do końca panowania Jana III (1513-1696), t. 2, Breslau MDCCCXXXVIII 

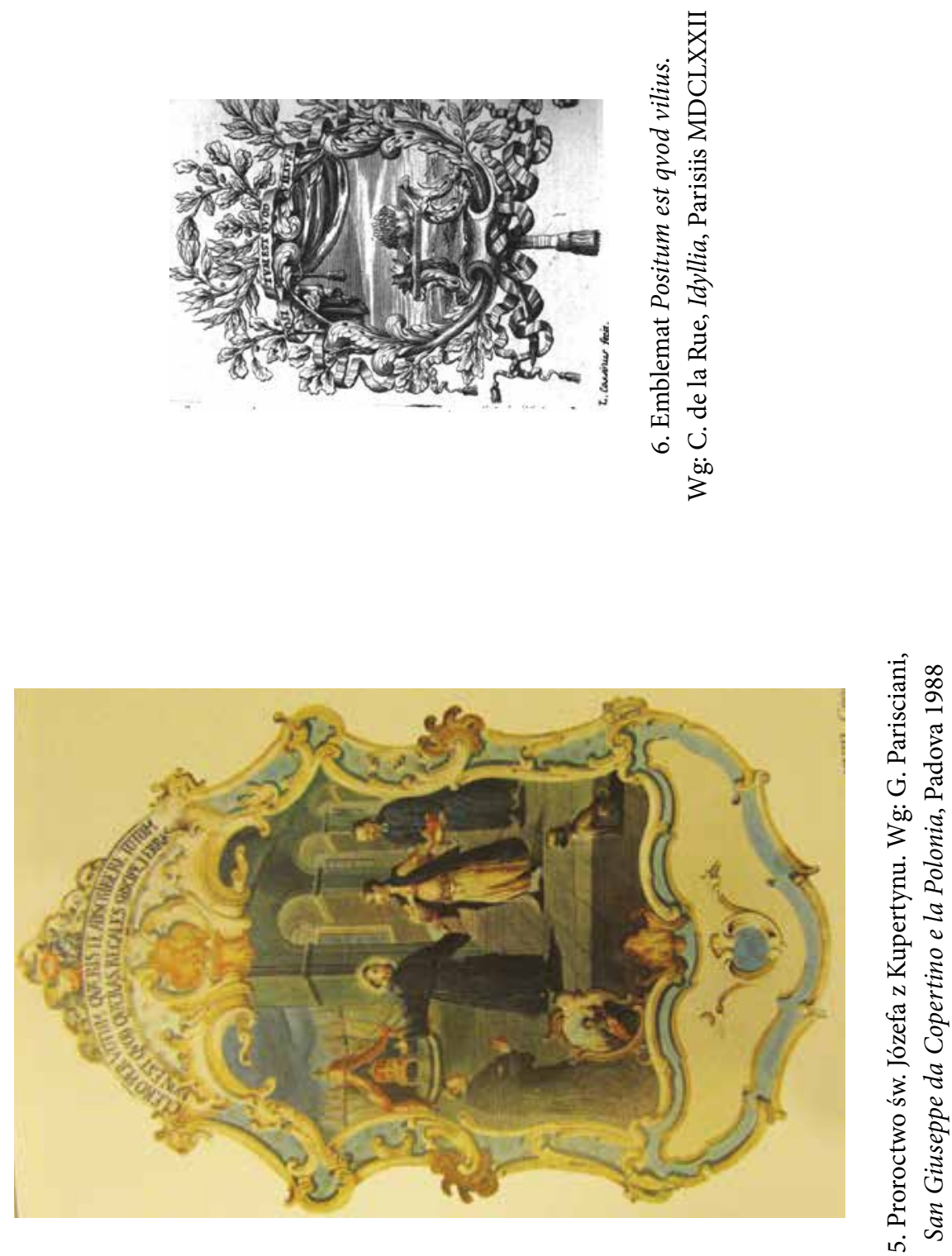


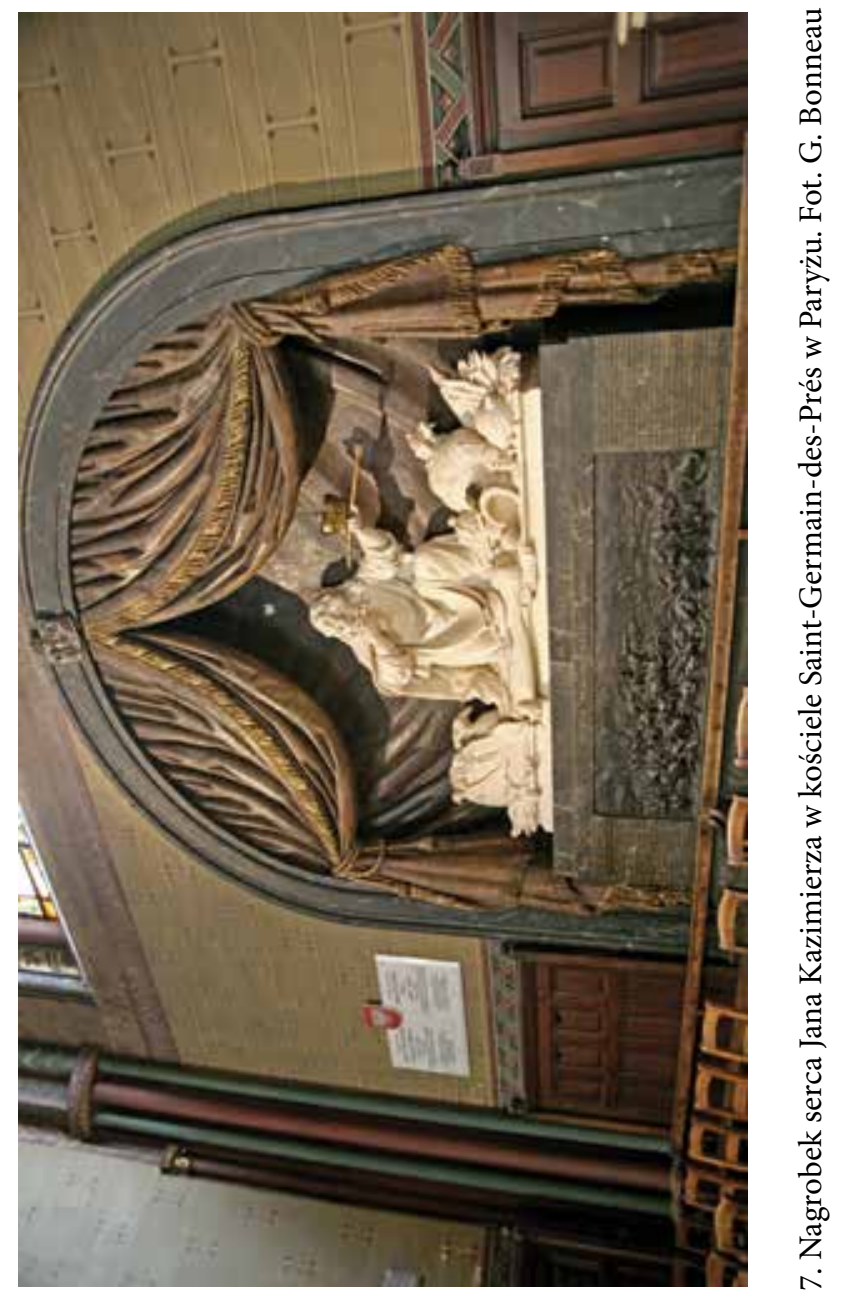

